Yayın Geliş Tarihi: 05.09.2016

Yayına Kabul Tarihi: 21.07.2017

Online Yayın Tarihi: 06.04.2018

http://dx.doi.org/10.16953/deusosbil.280561
Dokuz Eylül Üniversitesi

Sosyal Bilimler Enstitüsü Dergisi

Cilt: 19, Say1: 3, Y11: 2017, Sayfa: 417-439

ISSN: 1302-3284 E-ISSN: 1308-0911

Derleme Makalesi

\title{
VAROLUŞ FELSEFELERİ, VAROLUŞÇU TERAPİ VE SOSYAL HİZMET
}

Gizem ÇELIK*

$\ddot{O} z$

Varoluş felsefeleri, insanı ve insan yaşamını açılamaya çalışan felsefi akımları temel alarak; ancak onlardan farklılaşan önemli nitelikleri ile günümüz insanının sorunlarına yönelen ve tek bir tanımlamayla anılması mümkün olmayan, kimilerine göre bir felsefe yapma tarzını kimilerine göre ise bir felsefi iklimi ifade etmektedir. En yalın ifadeyle, insanı nesne gibi ele alan ve yorumlayan yaklaşımlara tepki olarak, insanın biricik ve otantik oluşu özelliği ile tanımlanması gereken bir varoluş olduğunu belirten varoluşçu görüş, pek çok insanî soruyu ele alıp işleyerek "öz-varoluş ilişkisi", "varlığın ve hayatın anlamı", "özgür iradenin insan davranışlarındaki rolü”, "sinırsız özgürlük ve sorumluluk", "varoluşsal anksiyete” gibi pek çok konuda açıklamalarda bulunmaktadır.

Bu çalışmada, varoluş felsefelerine ve temel niteliklerine ilişkin genel bilgilere, artan ve karmaşıklaşan insan sorunlarının çözümünde önemli açıklamalar getirmesi dolayısıly terapide yer bulan varoluşçu analizin özelliklerine ve odağı insan, insan sorun ve ihtiyaçları olan sosyal hizmet disiplin ve mesleğinin varoluş felsefeleri ile olan ilişkisine yer verilmektedir.

Anahtar Kelimeler: Varoluşçuluk, Varoluş Felsefeleri, Varoluşçu Terapi, Varoluşçu Analiz, Sosyal Hizmet.

\section{EXISTENTIAL PHILOSOPHY, EXISTENTIAL THERAPY AND SOCIAL WORK}

\begin{abstract}
Without a single definition, philosophies of existence sometimes described as the "way of making philosophy" or sometimes "climate of philosophy". It basically arose from philosophical trends which are trying to explain human and life but differentiates from them by focusing on the problems of the modern man. By the simplest terms, existential philosophy states that human being must be defined as unique and authentic existent and it has born as a reaction to the approach that takes human beings as objects. Existential philosophy takes and examines many humanitarian questions such as "self-existence relationship", "meaning of life and the existence", "the role of self-determination in human behavior", "limitless freedom and responsibility" and "existential anxiety".
\end{abstract}

\footnotetext{
* Yrd. Doç. Dr., İstanbul Medipol Üniversitesi, Sağlık Bilimleri Fakültesi, Sosyal Hizmet Bölümü, gizemcelik@medipol.edu.tr
} 
In this study, existential philosophy and its basic components are reviewed in general context and the characteristics of the existential analysis during therapy which brings important statements to the solution of complex and growing problems of human beings. Finally, social work and its important relationships with existential philosophy are analyzed from the perspective of its focus on human beings, their needs and problems.

Keywords: Existentialism, Existential Philosophy, Existential Therapy, Existential Analysis, Social Work.

\section{GíRIŞ}

"Hiçbir çağ bilgiyi bu kadar hızlı ve kolayllkla elde etmemiştir. Hiçbir çağda insanın ne olduğu hakkındaki bilgi bizimki kadar yetersiz olmamıştır. Hiçbir dönemde insan bu derece sorun haline gelmemiştir."

Heidegger

Varoluş felsefesi, farklı düşünürlerin benzer temalar üzerinde farklı yorum ve değerlendirmelerde bulundukları, çok boyutlu ve derinlikli bir felsefi akımdır. İnsana ve insanın varoluşuna yönelen bu felsefi akım aslında, kendinden önceki felsefi akımların da ele aldığı konuları incelemekte ancak getirdiği açıklamalar ve vurguladığı temalar bakımından farklılık göstermektedir. Öz-varoluş ilişkisi; insanın kendi özünü seçebilmesi ve buna bağlı gelen özgürlük ve sorumluluk; ölüm, yalnızlık, varoluşsal boşluk gibi varoluşsal sorunlar hem varoluş felsefelerini hem de bu felsefeleri temel alan varoluşçu terapiyi etkilemiş ve günümüz insanının sorunları bu bileşenlerle ele alınmaya başlanmıştır.

Sadece varoluşsal bir sorundan kaynaklı değil aslında varoluşsal bir ihtiyaç olarak da varoluşçu akımın önem kazandığını belirtmek gerekir. Çünkü insan denilen varlık, dünyada bulunuşuyla birlikte kendini olușturmakta ve bu yolla olgunlaşmaktadır. Alacağı dersler, yerine getireceği görevler, sahip olacağı rol ve sorumluluklar ve öğrendikleri ile kendini var ederek özünü oluşturabilecektir. Yalnız insana ait olan bu özellik, onun eşsizliğini belirtmenin yanı sıra yaşayacağı iç sıkıntısının ve öz arayışının da önemli bir nedeni olacaktır. İşte bu öz arayış ihtiyacıyla birlikte, varoluş felsefesinin temaları ve insana yaklaşımı, insanın kendini var etme sürecinde önemli bir kaynak olacaktır.

Aslında, sahip olduklarıyla biricik bir varlık olan ve büyük bir keşif içinde bulunan insanın bu özelliklerini fark etmesi, daha anlamlı, daha huzurlu ve belki de varoluşunu taçlandıran bir yaşam sürmesine neden olacakken, birçok insan bunların farkında değildir. İçinde bulunduğumuz savaş ortamı, sosyo-ekonomik krizler ve her gün artan stres altında insanlar özlerine bakmak ya da onu aramak yerine, yaşamda kalma mücadelesi vermektedir. Ancak bu mücadelenin çok da nitelikli olmadığı, artan fizyolojik ve psikolojik hastalıklardan rahatlıkla anlaşılabilir. İşte tam da bu noktada varoluş felsefeleri ve varoluşçu terapi, insana, insanca dokunuşlarla ve varoluşsal konularla yaklaşmakta ve onu desteklemektedir. 
İnsan ihtiyaç ve sorunlarına yönelen psikoloji ve psikiyatri gibi sosyal hizmet disiplin ve mesleği de varoluş felsefelerinin bu niteliklerinden kendi mesleki formasyonu çerçevesinde yararlanabilmektedir. Hatta sosyal hizmet değerleri ile oldukça paralel olan kimi ilkeler, sosyal hizmet uzmanlarının toplumun dezavantajlı ve kırılgan olarak nitelendirilen kesimleri ile yaptıkları çalışmalarda, varoluşçu yaklaşımı daha etkin kullanmalarını sağlayabilecektir. Çünkü ölüm, özgürlük, sorumluluk, anlam arayışı ve yalnızlık hissi, paylaşılan ortak konulardandır.

$\mathrm{Bu}$ çalışmada, her ne kadar varoluş felsefelerine, varoluşçu terapiye ve varoluş felsefelerinin sosyal hizmet ile olan ilişkisine yönelik genel ve kapsayıcı bilgiler verilmeye çalışılmışsa da konunun çok daha derin ve detaylı olduğunu belirtmek gerekmektedir. $\mathrm{Bu}$ nedenle bu çalışma, bu konuda ileride yapılacak araştırma, inceleme, uygulama ve değerlendirmelere bir giriş niteliğinde değerlendirilebilir.

\section{VAROLUŞ FELSEFELERI}

\section{“İnsanın varoluşu iyi ve kötünün ötesindedir."}

Nietzsche

Varoluş felsefesi, 19. yüzyılın sonlarında Almanya'da filizlenmiştir. Tüm insanlığı etkileyen dünya savaşlarından sonra daha çok konuşulan ve tartışılan bir felsefi akıma bürünen varoluş felsefesi, özüne ilişkin yapılan açıklamalardaki farklılıklardan dolayı tek ve geçerli bir tanımlama ile anılamamakta, varoluş̧̧u filozoflar tarafından yapılan tanımlamalar da daha çok varoluş felsefesinin bir boyutunu nitelediği için yeterli görülmemektedir. Asım Bezirci'nin Sartre'ın Varoluşçuluk isimli kitap çevirisinde yazdığ 1 önsözde, varoluş felsefesi, Jean-Paul Sartre'ye göre tanımlanması kolay bir felsefe (Bezirci, 2009: 7) olarak geçmektedir:

"Her nesnenin bir özü, bir de varllğı vardır. Öz, sürekli nitelikler topluluğu demektir. Varlık ya da varoluş ise, dünyada etkin olarak bulunuş demektir. Çoğu kimseler özün önce, varoluşun sonra geldiğine inanırlar (...) Öz, bir nesnenin özelliklerinin değişmez bütünlüğüdür; varoluş ise, evren içinde gerçek olarak bulunuşudur (...) Insanda, ama yalnı insanda varoluş özden önce gelir. Bu demektir ki insan önce vardır; sonra şöyle ya da böyle 'olur'. Çünkü o, özünü kendi yaratır..."

Sartre'nin yapmış olduğu bu açıklamanın yanında Heinemann, varoluşçuluğun gerçek bir tanımının yapılamayacağını; çünkü varoluşçuluk sözcüğünü kucaklayan tek bir öz, tek ve değişikliğe uğramayan bir felsefe olmadığını; sözcüğün, aralarında derin ayrımlar bulunan çeşitli felsefeleri gösterdiğini belirtmiştir (Bezirci, 2009: 8-9). Varoluş felsefesinin, farklı düşünce akımları ve kuramlarla ilişki kurduğunu, çeşitli felsefe tarihleri içindeki konumuna göre de farklı biçimlerde tanıtıldığını görmek mümkündür. 
Bireyciliğe aşırı yer vermek, kişinin varoluş sorununa büyük ilgi göstermek, herhangi bir düşünce okulundan olmamak, herhangi bir inanç kümesini ve sistemleri yetersiz görmek, gelenekçi felsefeyi küçümsememek (Kaufmann, 1964: 6-22; akt.: Bezirci, 2009: 9), özgür ve sorumlu özneye dikkat çekmek gibi temel nitelikleri olan varoluş felsefesi, çağımızın güç koşulları altında ezilen/baskılanan ve var olamayan insanının felsefesidir.

Varoluş felsefelerini anlamak için ortak ilke ve temalarına bakmak gerekmektedir. Gündoğdu (2007: 98), ortak ilke ve temalar arasında ayrım yapmak gerektiğini; varoluş felsefelerini sadece bazı ortak temalar etrafinda ortaya konan bir felsefi görüşler koleksiyonu olarak görmenin yanıltıcı olabileceğini vurgulamaktadır. Varoluşçu temaların çoğunun sadece varoluş felsefelerine özgü olmadığı, birçok filozof tarafından işlenen temalar olduğu açıktır. Ancak varoluş felsefelerini diğer felsefelerden ayıran; ele alınan temalara yaklaşım biçimi, değerlendirme yöntemi ve amacıdır. Kısaca ifade etmek gerekirse "ilkeleri"dir (Kuhn, 1949; akt.: Gündoğdu, 2007: 99).

Varoluş felsefelerini anlamak için ilkelerine bakılması gerektiği gibi, bu ilkelere ilişkin Hıristiyan varoluşçular ve Tanrı tanımaz varoluşçular açısından yapılan analizlere de değinmek gerekmektedir. Varoluş felsefesi ilkelerinin ele alındığ 1 ilerleyen sayfalarda bu yöndeki tartışmalara da kısaca değinilerek anlam bütünlüğü sağlanması hedeflenmektedir.

\section{Varoluş Felsefelerinin Temel İlkeleri}

Akılcılık, deneycilik ve tarihselcilik gibi bir düşünce okulu, bir öğreti ve tutarlı ortak bir inanış olmadığı açık olan (Gündoğdu, 2007: 99) varoluş felsefesinin, ilkelerinin de aslında her varoluşçu düşünür tarafından eşit ölçüde geçerli olmadığını akılda tutarak okumak ve yorumlamak gerekmektedir.

“Ínsanın Temel İlgi Konusu Olması” İnsanı tanımanın, bedeni tanımaktan daha kolay olduğunu değil, ama onu tanımanın, dünyayı ya da fikir yasalarını tanımaktan çok daha ivedi olduğunu düşünmektedir (Mounier, 2007: 49). Varoluş felsefesine göre insan, önceden tanımlanamaz ve belirlenemez. Kendini nasıl yaparsa öyle olur.

“İnsanın Somut Bir Özne ve Birey Olarak Görülmesi” Varoluşçular, insanın nesneleştirilmesine; doğanın, tarihin, toplumsal çevrenin, biyolojik ve fiziksel güçlerin ürünü bir nesne konumuna indirgenmesine itiraz etmekte ve özne olarak insanın emsalsizliğine vurgu yapmaktadırlar (Charlesworth, 1976: 71; akt.: Gündoğdu, 2007: 101).

“Varoluşun Özden Önce Gelmesi” Sartre bu ilkeyi açıklarken, her nesnenin bir varoluşu, bir de özü olduğuna vurgu yapmakta ve yalnız insanların diğer tüm varlıklardan farklı olarak varoluşunun özden önce geldiğini belirtmektedir. Ancak daha önce de ifade edildiği gibi varoluşçu ilkelerin tümü her varoluşçu düşünür tarafindan kabul edilmemekte, örneğin bu ilkede Marcel "İnsanı anlayacak Tanrı 
yoksa, insan da yoktur” diyerek Sartre'ın “varoluşun öze önceliği” ile kastettiği kendine özgü ateistik anlayışı kesin olarak reddetmektedir (akt.: Gündoğdu, 2007: 107).

“İnsanın Kendi Özünü Seçmesi” İnsanın, olmayı seçtiği şeyden başka bir şey olmadığı ilkesi, varoluş felsefesinin baş ilkesi olarak değerlendirilmektedir (Sartre, 2009: 40). Bu noktada tekrar Sartre ve Marcel'in görüş ayrılığı içinde oldukları anlaşılmaktadır. Sartre için özgürlük, yokluktan doğan değerleri ve varlığın özünü yaratan bir sebepken, Marcel için özgürlük iyilikten yararlanma ve varlığa bir katılmadır (Muşta, 1988: 63; akt.: Gündoğdu, 2007: 107).

Özgürlük, diğer felsefi akımlarda olduğu gibi varoluş felsefelerinde de tartışılan ve daha önce belirtilen "varoluşun özden önce gelmesi" ve "insanın kendi özünü seçmesi” ilkeleri ile yakından bağlantılı olan bir temadır. İnsanın kendini, varlığında değil, varoluş biçiminde seçebileceğini söyleyen Sartre (akt.: Foulquie, 1995: 55), durum karşısında alınan bu tavrın insanı değiştirmekte etken olduğunu; kendine bağlı olmayan bir alanda (örneğin fiziksel engele sahip olma, kısa boylu olma, düşük sosyo-ekonomik çevrede dünyaya gelme vb.) özgürlüğe bir kapı açılmış olduğunu, böylece etkisinin değişebileceği ve bireye göre biçimlenebileceğini belirtmektedir.

İnsanın özgürlük isteğine ilişkin Sartre, salt bireysel bir özgürlük arayışı ve istediğinden ziyade, diğerlerinin de özgürlüklerini gözeten bir anlayışla şunları da eklemektedir (Sartre, 2009: 70):

“(...) Ama özgürlüğü isteyince, onun tümüyle başkalarının özgürlüğüne, başkalarının özgürlüğ̈̈nün ise bizimkine bağlı olduğunu anlarız. Gerçi insanın tanımı olarak özgürlük başkalarına bağll değildir ama ortada bir bağlanma olunca iş değişir. O zaman kendi özgürlügümle birlikte başkalarının da özgürlüğ̈̈nü istemek zorunda kalırım. Başkalarının özgürlügüün gözetmezsem kendi özgürlüğümü de gözetemem."

İnsanın sınırsız özgürlük istemi, sorumluluk temasını da beraberinde getirmektedir. Sorumluluk, dışsal yapının yokluğuna gönderme yapan özgürlük sonundaki seçim, hareket ve yaşam tarzı sonuçlarının sorumluluğunu almayı ifade etmektedir.

Sartre (2009: 44-46), sorumluluk ve sorumlulukla bağlantılı bunaltıyı şöyle açıklamaktadır:

“(...) Her insan şöyle demelidir: 'Insanlı, edimlerime bakarak kendini ayarladiğına göre, böyle hareket etmekte hakl miyım? Yaptı̆̆ım doğru mu?' Ĕ̈er böyle demezse, bilin ki bunaltısinı maskelediğinden dolayı demiyordur (...) Sorumlulukları olan herkes bilir bu bunaltıyı / iç sıkıntısını." 
“Hakikat Öznelliktir” Gündoğdu (2007: 112), varlığa atılmış olan insanın yaşamda bir anlam bulma meselesinin, nesnel hakikat ile öznel kavrayış arasındaki ilişkiyi kökten değiştirdiğini ve bu değişimin Kierkegaard'ın "hakikat öznelliktir" sözüyle ifade edildiğini belirtmektedir.

Varoluş felsefesinin bu ilkesi, öznelcilik, keyfilik ve görelilik olarak değil, hakikate ulaşmak isteyen somut bireyin öznel konumuna önem verdiğini ve onun hakikatle olan varoluşsal ilişkisini ifade etmektedir. Kierkegaard'a göre söz konusu hakikat, insan kendisini davranışlarıyla yarattığında ortaya çıkmaktadır. Yani hakikat "birey onu eylemiyle ürettiği zaman olur" (May, 2012: 61).

“Aktörün Bakış Açısından Felsefe Yapılması” Charlesworth (1976: 23) felsefenin esas işini, dünyadaki varoluşumuzun altında yatan ilksel deneyimi açığa çıkarmak ve aydınlatmak olarak tanımlamaktadır. Bu anlamda, varoluşsal deneyimden kaynaklanan felsefenin, aktörün bakış açısından yapılması (Langiulli, 1997: 5) gerekmektedir. Bu ilke ayrıca, varoluş felsefelerinin ortak ilkelerinden; “insanın özne olması", "kendi özünü seçme özgürlügüu”, "sorumluluk" ve "hakikat öznelliktir" ilkeleriyle de oldukça paralel olan ve onları destekleyen niteliktedir.

\section{VAROLUSCCU TERAPİ VE TEMEL NITELIKLLRİ}

\section{"Dünyada varoluşçu psikiyatrist sayısı kadar varoluş̧̧u psikiyatri yaklaşımı vardır." \\ Viktor Frankl}

Köklü felsefi akımlara dayanan varoluş felsefeleri (Payne, 1997; Mounier, 2007), fenomonolojik ve ontolojik yapıdadır. Günümüzün duygusal ve ruhsal mizacının derin boyutlarının bir ifadesi (May, 2012: 59) olarak ifade edilen varoluş felsefelerinin, kendiliğinden ve genelde farklı alanlardaki insanların birbirlerinden habersiz benzer çalışmalar yaptığını bilmeden ortaya çıktığı (May, 2012: 49) görülmektedir. Köklerini aynı psikolojik krizlerden ve aynı tarihsel durumlardan alan bu akım, günümüz Batılı insanının psikolojik açmazının benzersiz ve özel bir tasvirini (May, 2012: 59- 60) sunmakta, insanın anlayış tarzında çok ciddi boşluklar olduğuna dair giderek büyüyen bir farkındalık yaşanmasıyla da (May, 2012: 47) psikiyatri ve psikoloji alanında kendini göstermektedir. Geçtan (2007: 31) bu durumu, "belirli kişilerin değil, çağın bir gereği ve ürünü olarak ortaya çıkmıştır" şeklinde açıklamaktadır.

Psikiyatride varoluşçuluk ${ }^{1}$, İkinci Dünya Savaşı'nı izleyen yıllarda, Batı Avrupa'da belirmeye başlayan ve giderek Amerika kıtasında da yaygınlaşan bir yaklaşım haline gelmiştir. Geçtan (2007: 25)'a göre, psikanaliz ve psikanalitik

\footnotetext{
${ }^{1}$ Her ne kadar bu felsefi akımın savunucularının büyük çoğunluğu "varoluşçuluk" terimini kullanmıyor olsa da psikoloji ve psikiyatri alanında bu terimin sıklıkla kullanıldığ görülmüştür.
} 
kökenli psikoterapi temelinde, Heidegger'in ontoloji denilen düşünce ekolünden esinlenerek geliştirilmiş bir tedavi tutumunu tanımlamaktadır. İsviçreli psikanalistler Medard Boss ve Ludwig Binswanger, "Daseinanalysis" adıyla geliştirdikleri tedavi yaklaşımıyla varoluşçu psikoterapinin öncüsü sayılmaktadırlar. Yalom (2001: 33), Avrupalı varoluşçu analitik eğilimin, hem felsefi kavramların insanın klinik incelemesine uygulanması arzusunun bir sonucu, hem de Freud'un insan modeline karşı bir tepki olarak doğduğunu belirtmektedir.

Psikiyatrideki konumu açısından değerlendirildiğinde varoluşçuluk, bağımsız bir tedavi "ekolü” olarak anılmamaktadır. İnsanı anlama çabasında, geleneksel psikolojik tedavilerin alışılagelmiş geleneksel yöntemlerinden temelden farklı bir "tutum"u yansitmaktadır (Geçtan, 2007: 26). Bu açıdan, varoluş̧̧u psikoterapi bir yöntem değil, tutum olarak nitelendirilmektedir.

Modern kültürün krizlerine cevap niteliğinde ortaya çıkan varoluşçu yaklaşım (May, 2012: 69), materyalizm ile idealizm arasındaki o eski ikilemi dağıtan bir seviyede, insanı analiz edip betimleme (May, 2012: 60) amacındadır. İnsanları, kendi gerçeklerinde inceleyen bir insan biliminin gerekli ve mümkün olduğu konusunda 1srarlı (May, 2012: 64) olan düşünürler ve bilim insanları, insanı hesaplanabilen ve kontrol edilebilen bir nesne olarak ele alma tavrına karşı çıkmışlardır (May, 2012: 61).

Binswanger (1956: 145; akt.: May, 2012: 51)'a göre, varoluşçu analitik temele sahip psikoterapi, tedavi edilen hastanın yaşam tarihini araştırmaktadır. Ancak bu araştırma, herhangi bir psikoterapi ekolünün öğretileriyle ya da o ekolün tecrit ettiği kategorilerle açıklanmamaktadır. Bunun yerine yaşam tarihi, kişinin dünyada oluşunun bütün yapısına getirilen bir değişiklik olarak anlamaya çalışılmaktadır. Bu noktada önemli olan ve altı çizilmesi gereken, anlamanın teknikten önce gelmesidir. Dolayısıyla varoluşçu terapistin tekniği, tedaviye gelen bir kişiden diğerine, aynı kişinin tedavi süreci içinde bir evreden diğerine değişebilen bir esneklik göstermektedir (Geçtan, 2007: 49-50). Terapi sürecindeki bu özgünlük, terapist ile danışan arasındaki ilişkiye de yansımaktadır. Geçtan (2007: 50) bu ilişkinin, terapistin danışanının "dünyasına katılarak" gerçekleştirebileceğini belirtmektedir. $\mathrm{Bu}$ da terapistin kişiye görüngübilimsel (fenomonolojik) olarak yaklaşması gerektiği anlamına gelmektedir. Başka bir ifadeyle terapistin, danışanının yaşantısal dünyasına girmesi ve anlayışı bozan varsayımlarda bulunmadan, bu dünyanın olgularını dinlemesi demektir.

Tedaviye gelen kişiyi, "onun kendi dünyası içinde" anlamaya çalışmak ile anlatılmak istenen; kişinin çevresindeki insanlar dünyası değil, içinde var olduğu kendine özgü dünyası ve bu dünyaya ilişkin anlayış geliştirmedir. Geçtan (2007: 46), Kierkegaard, Nietzsche ve diğer varoluşçuları referans göstererek; batı dünyası insanının yaşadığı anksiyete ve umutsuzluğun kökeninde "kendi dünyalarını kaybetmiş olma" olgusunun bulunduğu görüşünü paylaşmakta, çağdaş insanın insanlar dünyasına yabancılaşmasının yanı sıra, kendi dünyası içinde de tutsak durumda olduğunu belirtmektedir. Bu nedenle, varoluşçu terapistin ya da düşünürün 
görevi; insanın baştan beri bildiği, bastırılmış bir şeyi yüzeye çıkarmak ve bunu, kişinin yeniden tanımasını sağlamaktır.

Hem öznelliğin hem de nesnelliğin altında yatan gerçeklikle ilgilenen (May, 2012: 65) varoluşçu analize göre gerçek, "yaşanan anda", insanın kendi dünyasında yaşananlardır (Geçtan, 2007: 30-31). Bu açıdan varoluşçu psikiyatrinin, varoluşun zaman boyutuna önem verdiği belirtilebilir. İnsanı "-dır", "-mış", “-di” durumları yerine, "-yor" ya da "-makta" takısının ifade ettiği gibi, "her an olmakta olan" bir süreç olarak ele almaktadır (Geçtan, 2007: 46- 47).

Varoluşçu yaklaşımın önemli konularından biri olan "var olmamak", "hiçlik" ve bunlarla bağlantılı anksiyete ve bunaltı, var olmanın ayrılmaz bir parçası olarak görülmekte ve var olmanın anlamını kavrayabilmenin, yok olmanın her an mümkün olabileceğini kavrayabilmiş olmayı içerdiği belirtilmektedir. İnsan, doğmuş olduğunu ve bir gün öleceğini bilen tek canlıdır ve ölüm, var olmamanın en somut biçimidir. Kuşkusuz ölümün kaçınılmaz olduğu gerçeği, insanın yaşamını gözden geçirmesi ve sonlu yaşamında doyumlu ve anlamlı bir yaşam yaşayıp yaşayamadığını sorgulamasına, yokluk ve hiçlik duygusu hissetmesine ve buna ilişkin anksiyete geliştirmesine neden olmaktadır. Geçtan (2007: 41) bu anksiyete duygusunu yaşamak istemeyen birçok insanın, kolektif tepkiler ve tutumlar yığını içinde eriyip yok olmayı seçtiklerini belirtmektedir. Bunun yan ürünü olarak, günümüz konformizmine kapılıp yok olmaya karşı gelmeme ve var olamayarak yaşamak da sık gözlemlenen bir başka biçimdir (Geçtan, 1974: 14). Her iki durumda da insan, yaşamının en az bir döneminde, söz konusu bu varoluşsal gerçekle yüzleşmektedir. Bu noktada takınacağı tavır, özü gereği kendi seçimini yansıtacaktır.

Varoluşçu düşünürlere göre, varoluşa dair yaşanan anksiyeteden kurtulmak için çoğu insan özgürlüğünden kaçınmayı yeğlemekte, daha önce de ifade edildiği gibi var olmamayı seçebilmektedir. Ontolojik suç olarak kavramsallaştıran olgu, "suçluluk duygusu yaşamaktan farklı bir olgudur. Çünkü kişi gerçekten suçludur" (Geçtan, 2007: 45).

Geçtan (2007: 45- 46)'a göre ontolojik suçun önemli bir özelliği, bu olgunun herkes tarafindan yaşanmasıdır. Ontolojik suç ayrıca, içinde yaşanılan kültürün değer yargılarına uygun davranıldığında ya da toplum beklentileri yerine getirilmediğinde yaşanan suçluluktan farkl1, varoluşun gerçeklerinden haberdar olmaktan kaynaklanan bir olgudur. "Varoluşsal anksiyete" başka bir kavramsallaştırma ile "ontolojik anksiyete", anlamsız bir dünyadaki sınırlı yaşama anlam katılıp katılmadığı konusunda yaşanan bir kaygıyı ifade ederken; ontolojik suç, bu sorumlulukla yüzleşmekten kaçınmanın yarattığı bir olgudur.

Kişinin yaşamında hiçbir anlam olmadığını keşfetmesinin ardından yaşadığı korku ve panik duyguları ile karakterize edilen varoluşsal anksiyete, varoluşçu psikoterapinin odaklandığ önemli konulardan biridir. İnsanın kendini kurtarabilmesi için kendine şimdiye kadar olduğundan daha başka bir gözle bakması gerektiği vurgusu, yeni bilincinin ona var olmanın en doğru yolunu göstereceği yönündeki 
inanış, terapi sürecinde genellikle insanın seçme özgürlügünün vurgulanması; boşluk, kaygı ve sıkıntı duygularını azaltıcı yaşam tarzı geliştirmesi yönünde kendini göstermektedir (Gaidenko, 1966: 44-45; akt. Güleç, 2010: 43).

Varoluş felsefelerinin terapiye katkılarının özetlendiği bu bölümde son olarak, Binswanger'in "Daseinanalysis" adıyla geliştirdiği tedavi yaklaşımındaki Dasein kavramının da incelenmesi gerektiği düşünülmektedir. Varoluşçu düşünürlerden Nietzsche, insan varoluşunu dasein olarak ifade ederken Heidegger, insandan her zaman Dasein olarak bahsetmektedir. May (1994: 25), Almanca kökenli Dasein sözcüğünü "burada olmak (being in the world)" anlamında kullanmaktadır.

Nietzsche'ye göre Dasein yani insan varoluşu; yaşam kavramına, istenç duymaya, eyleme geçmeye ve olmaya dair bir genelleme olarak ifade edilmektedir (May, 2012: 101). İnsanın Daseinini geliştirmesi için de sürekli çaba göstermesi, anlamlı yaşam sürmenin yolunu araması ve varoluşsal anksiyete ile yüzleşmesi gerekmektedir.

May (1994), insanların birbirleriyle eş zamanlı üç ayrı tarz dünyada var olduklarını belirtmekte ve bu dünyaları umwelt, mitwelt ve eigenwelt ${ }^{2}$ olarak ifade etmektedir. Umwelt kişinin farkında olsun olmasın varlığını sürdürecek olan fizyolojik ve fiziksel nesneler dünyasını tanımlamaktadır (May, 1994: akt.: Yazgan İnanç ve Yerlikaya, 2011: 336). Umweltten gitgide uzaklaşan insanın yaşadığı bu ontolojik suçu May (1958), "ayrılma suçluluğu" olarak adlandırmaktadır (akt.: Yazgan İnanç ve Yerlikaya, 2011: 339).

Mitwelt ise, insan yaşamının sadece umweltten oluşmadığını, insanın diğer insanlarla kurduğu ilişki dünyasını yani sosyal dünyasını tanımlamaktadır. Heidegger'de mitwelt, Daseinin dünya ile kurduğu zorunlu ilişki (Mounier, 2007: 186) olarak ifade edilirken May (1994), diğer insanlarla ilişki kurma ihtiyacının doğuştan geldiğini belirtmektedir.

Son olarak eigenwelt, insana özgü özfarkındalık dünyasıdır. Eigenweltte yaşamanın, kişinin bir insan olarak kendisinin farkında olması, yani nesneler ve insanlar dünyası ile ilişki kurarken kim olduğunu kavraması (Yazgan İnanç ve Yerlikaya, 2011: 336) anlamını taşıdığı söylenebilir. Eigenweltin bozulması, boşluk duygusu ve kendine yabancılaşmayı getirmektedir. May (1958)'e göre sağlıklı insanlar, belirtilen üç dünyada da eş zamanlı bir şekilde yaşamaktadırlar (akt.: Yazgan İnanç ve Yerlikaya, 2011: 337).

Özetlemek gerekirse, nesnelerle dolu bir dünya ve bu nesneleri algılayan öznelere dair Kartezyen görüşe meydan okuyan varoluşçu görüşün amac1, insanı anlamadır. Burada belirtilen insan, "olması gerekeni yapayım derken olmakta olanı yaşayamayan” (Geçtan, 2007: 37), varoluşuna ilişkin düşünmeyen, varoluşsal

${ }^{2}$ Kavramların Türkçe karşılıklarını tam anlamıyla içeren kavramlar bulunamadığı için literatürde Almanca haliyle verildiği ve açıklandığı görülmüştür. 
kaygılarla yüzleştiğinde kaçan, kaçması sonrası ontolojik suçluluk duyan ve aslında var olamayan insanlar topluluğudur. Kierkegaard, Heidegger, Jean-Paul Sartre, Nietzsche gibi düşünürlerin varoluş felsefelerine ilişkin yaptıkları değerlendirmeler, varoluşçu terapiye yararlanabileceği güçlü bir kaynak sağlamıştır.

\section{VAROLUS FELSEFELERİ VE SOSYAL HIZMET}

Sosyal hizmet, insan refahını sağlamak, insanı özgürleştirmek ve yaşam kalitesini yükseltmek amacıyla çeşitli düzeylerde (birey, aile, grup, örgüt, toplum, politika, araştırma) uygulamalar gerçekleştiren bir disiplin ve meslektir. İnsanı, insan ihtiyaçları ve sorunlarını bütüncül bir yaklaşımla ele alan sosyal hizmet bilgi, beceri ve değer temelinde uygulamalar gerçekleştirmektedir. Sosyal hizmetin eklektik bilgi temeli, farklı meslek ve disiplinlerin bilgilerinden de yararlanılarak, sosyal hizmet bilgisi oluşturulduğunu ve uygulamalardan gelen bilgilerin de eklemlendiği bilgi kaynağını ifade etmektedir. İnsan, insanın çevresi, yaşam döngüsü, ihtiyaç ve sorunları, gelişim görevleri, kuramsal yaklaşımlar, yasal ve politik düzenlemeler, hizmetler vb. konulardaki bilgi kaynağı, müracaatçı yararına olacak şekilde sürekli gelişmekte ve değişmektedir.

Sosyal hizmetin beceri boyutu; iletişim, analitik düşünme, sorun çözme ve insanla çalışma yeterliğini ifade ederken değer boyutu, tüm bu bilgi ve becerilerin nasıl sunulmas1, insana nasıl yaklaşılması gerektiğini belirtmektedir.

Sosyal hizmet meslek ve disiplininin odağ 1 , insan ve temel hedefi de insanın iyilik halini sağlamaktır. Sosyal hizmetin yoğunlaştığı ve uygulamalar gerçekleştirdiği sorun alanları çeşitli ve çok boyutlu olmakla birlikte temelde mücadele edilen konular acı, adaletsizlik ve eşitsizlik karşısında hissedilen duygular, anlamsızlık hissi, baskı ve ayrımcılıktır (Fraternali, 1998: 63). Varoluş felsefelerinin temel nitelikleri, sosyal hizmetin değerleri ile birleştirildiğinde bu sorun ve ihtiyaçların üstesinden gelmek daha kolay olabilmektedir. Çünkü hem varoluş felsefeleri hem de sosyal hizmet, insanın biricikliğine vurgu yaparak, her insanın özgür ve bağımsız birer birey olduğuna, bu anlamda kendi sorumluluklarını almaları ve seçimlerini yapmalarına, bunu yaparken de kendilerini tanımaları ve yaşamın anlamına ulaşmalarına vurgu yapmaktadır. Bu anlamda, varoluş̧̧u terapide tartışılan "varoluşsal boşluk (existential vacuum)" un (Frankl, 2009) sosyal hizmet uygulamaları ile doldurulabileceği söylenebilir.

Varoluşçu analiz ve sosyal hizmet ilişkisinin detaylarına, tarihsel gelişime ilişkin kısa bir girişle başlamakta yarar olduğu düşünülmektedir. Daha önce de belirtildiği gibi, varoluşçu terapinin kökleri varoluş felsefelerine dayanmaktadır. Varoluş felsefeleri, 19. yüzyıl filozoflarından Soren Kierkegaard (1844/1980, 1849/1980b), Friedrich Nietzsche (1844-1900), Martin Buber (1878-1965); Martin Heidegger (1889-1976); Fransiz yazar Jean-Paul Sartre (1905-1980) ve Albert Camus (1913-1960) ile başlamış; 20. yüzyılda İsviçreli psikiyatrist Ludwig Binswanger (1881-1966)'in "daseinanalysis" yöntemi ile ve Avusturyalı 
psikiyatrist Viktor Frankl (1905-1997)'in logoterapi yöntemi ile psikoterapi alanında kullanılmaya başlamıştır. Daha sonra, Irvin Yalom (1980 ve sonrası), Rollo May (1958 ve sonrasi) ve James Bugental (1981 ve sonrası) gibi isimler de varoluşçu görüşü işlemişlerdir (Randall, 2008: 323-324).

Varoluşçu yaklaşımın sosyal hizmet uygulamasındaki kullanımında iki önemli isim öne çıkmaktadır; Donald Krill $(1978,1986)$ ve Jim Lantz $(1993,1994)$. İlerleyen süreçte varoluşçu sosyal hizmet literatürüne Brown ve Romanchuk (1994) ve Randall (2001) dâhil olmuştur. Kominkiewicz (2006: 48), varoluşçu düşünürlerden Heidegger' in varoluş felsefesini ele aldığı makalesinde, Heidegger'in varoluşçu görüşünün kuramsal temellerinin sosyal hizmet literatüründe çok az yer aldığını belirtmektedir. Bunun yanında, varoluş̧̧u yaklaşıma dayalı uygulamaların sosyal hizmet alanlarında başarılı bir şekilde ele alındığını belirten Kominkiewicz (2006), felçli hastaların sağaltımında (Nilsson, Jansson ve Norberg, 1999), klinik sosyal hizmet uygulamasında (Klugman, 1997), adölesanlarla gerçekleştirilen çalışmalarda (Chessick, 1996; Hacker, 1994), yaşlılara yönelik sosyal hizmet uygulamalarında (Brown ve Romanchuk, 1994), aile tedavisinde (Boylin ve Briggie, 1987; Haldane ve McCluskey, 1982; Kaye, 1986; Lantz, 1987; Lantz ve Kondrat, 1997), evli çiftlerle yapılan uygulamalarda (Lantz, 1999), çocuk istismarında (Brown, 1980), sosyal hizmet süpervizyonunda (Walsh, 1999), madde kullananların sağaltımında (Ford, 1996), savaş gazileri ile gerçekleştirilen çalışmalarda (Lantz, 1991; Lantz ve Greenlee, 1990) ve sosyal hizmet eğitiminde (Dean ve Fenby, 1989; Peebles ve Suval, 1983) kullanıldığını belirtmektedir.

Fraternali (1998: 65), varoluşçuluğa psikoloji ve psikoterapide oldukça fazla yer verilirken (Frankl, 2009; Yalom, 1980; May, 1961), sosyal hizmetin varoluşçu anlayıştan özellikle kaçındığını belirtmektedir. Varoluşçuluğun sosyal hizmet ile doğrudan ve derinliği olan birlikteliğini Donald Krill (1978) ve Neil Thompson (1992) savunmaktadır. Stretch (1967), Lantz ve Pegram (1989) varoluşçuluğun sosyal hizmet için tercih edilen yönünü vurgularken, Vandenberg (1991) ve Bilsker (1992) kimlik oluşumu ve gelişimini anlamada varoluşçuluğa başvurmakta ya da Brown (1980) ve Hacker (1994), belirli nüfus grupları ya da işlevsizliklerde varoluş̧̧uluğun etkililiğini tartışmaktadır (akt.: Fraternali, 1998: 65).

Krill (1967), insan işlevsizliklerinin çoğunun altında yatan yabancılaşmanın çözümlenmesi ve bireyin diğerleri ile anlamlı ilişkiler kurmasına yardımcı olma amacıyla, varoluşçu sosyal hizmetin araç olarak kullanılabileceğini belirtmektedir. Krill (1967; akt.: Fraternali, 1998: 65) ayrıca, varoluşçu sosyal hizmeti hem temel sosyal hizmet ilkeleri hem de diğer kuramsal yönelimlerle (Gerçeklik terapisi, Geştalt terapi, Bilişsel ve Müracaatçı merkezli terapi) tamamen uyumlu bulmaktadır.

Sosyal hizmet ilkelerinde sıklıkla vurgulanan özgür seçim ve özgür eylem, şu anki yönelim ve gelecek yönelimi, toplumla ve diğerleri ile olan ilişkilerin kalitesiyle bağlantılı olarak bireysel kimliğin tanınması, müracaatçının bulunduğu yerden başlama ve müracaatçının öznel gerçeklik algısını kabul etme, tüm varoluşsal düşünce unsurlarını içermektedir. Uygulamaya rehberlik etmesi için Krill (1992; 
akt.: Fraternali, 1998: 65) beş terapötik kavramdan ya da varoluşçu sosyal hizmet sürecinin beş temel görevinden bahsetmektedir. Bunlar; hayal kirıklı̆gl, seçim özgürlüğü, acıdaki anlam, diyalog gerekliliği ve anlaşmadır. Bu görevleri Krill (1992) şöyle açıklamaktadır (akt.: Fraternali, 1998: 65- 66);

"Varoluş̧̧u sosyal hizmet uzmanlarına göre patoloji, gelişimin yakalanması değil, gelişimin öz-seçimle bozulmasıdır. Müracaatçılar, gelişimlerini engelleyen herhangi bir durumla karşılaşıtıklarında doğal olarak kendilerini koruma çabasına girerler ve bu hayal kırıklığ ile sonuçlanır. Kendini koruma çabalarl, suçlama, geçmişe bağlı kalma ve kaderin pasif kabulüyle özgürlüğü gasp etme şeklinde değişime direnmede otantik olmayan tutumlar içermektedir. Bu noktada sosyal hizmet uzmanının rolü, müracaatçıyı bir bütün, otantik ve biricik insan olarak ele alıp, söz konusu koruma çabalart ile hayal kırıklı̆̆ını deneyimlemesine yardımcı olmaktır. Çünkü kendini kandırma ve kötü kader, seçim özgürlüğünün yadsinmasina neden olabilir. Bu nedenle, sosyal hizmet uzmanının müracaatçının değişme kapasitesini görmesini sağlaması gerekir.

(...) Acıdaki anlam konusunda sosyal hizmet uzmanı, acıyı değişim için hem gerekli hem de yönlendirici olarak yeniden tanımlayarak, müracaatçının gerçekliğini onaylamalıdır. Bu, müracaatçının değişim motivasyonunu ve güçlerini arttıracaktır (...) Manipülatif olmayan açık iletişim, değişim için ön koşuldur. Diğerleri ile olan dürüst diyalog, müracaatçının sadece samimiyetini yansitmasını sağlamayacak, aynı zamanda müracaatçıya kendi ihtiyaçlarını anlamada yardım edecektir."

Varoluşçu yaklaşım ile sosyal hizmet uygulamalarına ilişkin genel bir kavrayış elde etmek için Thompson (1992; akt.: Payne, 1997: 196)'ın, yapmış olduğu varoluşçu analiz ilkeleri ve uygulama sonuçları karşılaştırmasına bakılabilir (Bkz. Tablo 1). 
Tablo 1: Varoluşçu Sosyal Hizmete İlişkin Uygulama İlkeleri

\begin{tabular}{|c|c|}
\hline$\dot{I} L K E$ & UYGULAMA SONUÇLARI \\
\hline $\begin{array}{l}\text { Özgürlük ve sorumluluk, insan } \\
\text { yaşamının en önemli yapı taşıdır. }\end{array}$ & $\begin{array}{l}\text { Müracaatçıların davranışının kesin ve değişemez } \\
\text { olduğu akla getirilemez. Müracaatçıların seçimler } \\
\text { yapabileceği ve onlara bu konuda yardımcı } \\
\text { olunabilecek yaşam alanlarının aranması, } \\
\text { müracaatçıların seçimlerini kısıtlayan durumların } \\
\text { tespit edilmesi ve onların ortadan kaldırılması. }\end{array}$ \\
\hline Özgürlük, nimet ve külfettir. & $\begin{array}{l}\text { Özgürlük kapsamındaki kaygı, korku, "kötü } \\
\text { inanış" gibi olumsuz açıların, öz-kontrol, güven, } \\
\text { öz- saygı, içtenlik gibi duygulara dönüştürülmesi. }\end{array}$ \\
\hline $\begin{array}{l}\text { Otantiklik/Özgünlük kurtuluşa } \\
\text { götüren en iyi yoldur. "Kötü } \\
\text { inanış" sorunlarla mücadele } \\
\text { açısından genelde başarısız bir } \\
\text { stratejidir. }\end{array}$ & $\begin{array}{l}\text { Sosyal hizmet uzmanları, özgünlük yaklaşımını } \\
\text { esas almalıdırlar; kendi ve başkalarının } \\
\text { yaşamlarına bir farklılık katabilecek nitelikteki } \\
\text { kapasitelerini kabul etmeli ve kullanmalıdırlar. } \\
\text { Müracaatçıların otantiklik kurması diğer } \\
\text { çalışmaların yapılabilmesini sağlayacaktır. Aksi } \\
\text { halde, yaşamlarını yönetebilmek için başkalarına } \\
\text { bağlı olacak ve kurallar içinde boğulacaklardır. }\end{array}$ \\
\hline $\begin{array}{l}\text { Varoluş, "güçsüzlük" olarak } \\
\text { kendini göstermektedir; } \\
\text { sorumluluk, herkes tarafından } \\
\text { kabul edilmelidir. }\end{array}$ & $\begin{array}{l}\text { Müracaatçılar, çok büyük sorunlarla karşılaşırlar. } \\
\text { Uzmanlar müracaatçlarına, alan ne kadar sınırlı } \\
\text { olursa olsun sorumluluk almaya başlamaları } \\
\text { konusunda yardımcı olmalıdır. Bunun } \\
\text { başarılmasıyla birlikte daha fazla kolektif } \\
\text { sorumluluğun üstlenilmesi (örneğin, bir ailedeki } \\
\text { dayanışma veya siyasi bir eylemde bir araya } \\
\text { gelinmesi) sağlanabilir. }\end{array}$ \\
\hline
\end{tabular}

Varoluşçuluk paylaşımlı öznel bir

Başlangıç noktası, müracaatçıların yaşantılarına seyahattir ve ortaklık yaklaşımını gerektirir. ilişkin duyguların kabul edilmesi ve eyleme geçmek için sorumluluk üstlenme sürecinin paylaşılmasıdır.

Otorite/ kontrol/ yasal görev ile yönlendirici olmayan yaratıcı bir Sosyal hizmetin bu iki açısı arasındaki karmaşık çatışmaları anlamak ve görmek, müracaatçıların çalışma arasındaki gerilimi tanımak bir görüş yaratan çatışmaların tanınmasında ve yönetmek ayrılmaz bir parçadır.

Varoluş bir akımdır.

Doğal istikrar mümkün değildir. Sosyal hizmet, parçalanmadan ziyade gelişim ve ilerlemeyi bulmaya çalışmaktadır.

Varoluşsal özgürlük ve kendini yaratma süreci, siyasi özerkliğin İlki, ikincisine ulaşmanın mümkün hale gelmesinden önce temin edilmelidir. temelidir.

\begin{tabular}{l} 
Kaynak: Payne, M. (1997). "Humanist and existential perspectives." İçinde Modern \\
social work theory (174-198). (Second Edition). NY: Palgrave Machmillan LTD. \\
\hline
\end{tabular}


Thompson'ın yapmış olduğu bu özet değerlendirme ile varoluşçu sosyal hizmet uygulama süreçlerine bakmak yerinde olacaktır.

\section{Birey Odaklı Varoluş̧̧u Sosyal Hizmet}

Sosyal hizmet uygulaması, genellikle altı temel aşamada (tanışma, bilgi toplama, planlama ve kontrat yapma, uygulama, sonlandırma ve değerlendirme) ele alınmaktadır. Varoluşçu sosyal hizmet uygulama sürecini de bu aşamalarda incelemek mümkündür. İlerleyen sayfalardaki açıklamalar, Randall $(2001,2008)$ 'ın çalışmalarının temel alındığı, varoluşçu sosyal hizmet uygulaması aşamalarına ilişkin genel ve özet bilgi niteliğindedir.

Tanışma Müracaatçı ile kurulacak profesyonel yardım iliş̧isinin ilk aşamasını oluşturan tanışma ve bazı kaynaklara göre ilk kabul, oldukça önemli bir aşamadır. Sosyal hizmet uygulama ilkelerinde de sıklıkla vurgulandığı gibi, tanışma aşamasında samimiyet ve güven ön plana çıkmaktadır. Varoluşçu yaklaşımla yapılanan sosyal hizmet uygulamasının tanışma aşamasındaki terapötik ilişki de güven ve otantikliğe (özgünlüğe) dayanmaktadır. Randall (2008: 328), Yalom (2002)'un özellikle son çalışmalarında, müracaatçının sorduğu tüm sorulara açık cevap verme ve kendini açma konusunda herhangi bir sınır olmayan yaklaşımı benimsediğini belirtmektedir. Yalom ayrıca, müracaatçı ve terapist arasındaki ilişkinin aktif, burada ve şimdiyi ele alacak süreç analizi şeklinde olması gerektiğini vurgulamaktadır.

Sosyal hizmet etik ilkeleri çerçevesinde düşünüldüğünde, müracaatçı ve uzman arasındaki ilişkinin, ilkelerin ötesinde bir samimiyetle kurulmasının mesleki yardım sürecini olumsuz yönde etkileyebileceği yönünde görüşler bulunmaktadır (Randall, 2008: 329). Bilindiği üzere, uzmanın kendini açması, belli müracaatçı gruplarında, uygun zamanda ve belirli ölçülerde gerçekleşmektedir.

Bilgi Toplama ve Ön Değerlendirme Sosyal hizmet uygulama aşamalarının bu düzeyinde, müracaatçının sorun ve/veya ihtiyacına yönelik olarak çeşitli kaynaklardan (müracaatçının kendisi, müracaatçının onayı ile gerekirse ailesi, arkadaşları, müracaatçı ile ilgili olan diğer profesyoneller, ilgili dosya ve formlar vb.) bilgi alınmaktadır. Varoluşçu sosyal hizmet uygulamasında toplanan bilgiler, az önce belirtilen deneysel ya da veri güdümlü yaklaşımdan ziyade daha çok, niteliksel ve deneyimsel yaklaşımla edinilmektedir. Hiç kuş̧usuz bu yönelimde, varoluşçu yaklaşımın felsefi köklerinin ve temel niteliklerinin büyük etkisi bulunmaktadır.

Randall (2008: 329) bu aşamada, müracaatçının ilgilerini keşfetmenin öncelikli amaç olduğunu belirtmektedir. Bu aşamada sosyal hizmet uzmanı/terapist, müracaatçısının, kendi dünya görüşüne ve duygularına dokunması ve onlar için önemli olan değerler ve yaşam seçimlerini tanımlaması için müracaatçısını cesaretlendirmektedir. Müracaatçı ayrıca, ümitlerini, arzularını ve dileklerini açık bir şekilde ifade etmesi için desteklenmektedir. Randall (2008: 330) ayrıca, varoluş̧̧u terapistlerin rutin klinik girişim olarak verilen psikoaktif ilaç tedavisi konusunda ilgisiz olduklarını belirtmektedir. 
Planlama ve Anlaşma Yapma Sosyal hizmet uygulamasındaki bu aşama, sosyal hizmet uzmanının müracaatçı ile birlikte müracaatçının ihtiyacına ve/veya sorununa yönelik çeşitli çözüm yolları belirledikleri ve bunları öncelik sırasına koydukları süreci ifade etmektedir. Planlanan sürece uygun olarak yazılı ya da sözlü anlaşma yapılmakta, böylece hem sosyal hizmet uzmanı hem de müracaatçı üstendikleri görev ve sorumluluklar konusunda açık olmaktadır. Bu süreçte her ne kadar "müracaatçı için müracaatçı ile birlikte" ilkesi göz önünde bulunduruluyor ve buna uygun hareket ediliyorsa da varoluşçu yaklaşımı temel alan sosyal hizmet uzmanları/terapistler için bu aşama oldukça yönlendirici ve kontrol edici yapıdadır (Randall, 2008: 330). Randall (2008: 330) çoğu varoluşçu terapistin, uzun süreli vakalarla yaptıkları çalışmalarda, müracaatçının randevularına devam etmeyi sürdürmesi ve anlamlı katılım göstermesi için toplantılarda ya da toplantılar arasında anlaşma yapma eğiliminde olduklarını belirtmektedir.

Uygulama Uygulama aşaması, planlanan hedefler doğrultusunda çalışmalar gerçekleştirmeyi içermektedir. Müracaatçının çeşitlilik gösteren ve etki alanı geniş sorun ve ihtiyaçlarına odaklanan varoluşçu terapilerde, daha önce de belirtildiği gibi terapist ve müracaatçı, konuya ilişkin birlikte tartışmakta ancak müracaatçılar yaşamları için en iyi hayat tarzının ne olduğuna kendileri karar vermektedirler (Corey, 2005: 150; akt.: Randall, 2008: 330). Kendi özünü seçen müracaatçı ayrıca, içsel değer biçme süreçlerindeki duygularına da açıklı getirmektedir. Özgürlük, sorumluluk, varoluş anksiyetesi, ontolojik suçluluk gibi varoluşçu analizin sıklıkla üzerinde durduğu konular uygulama sürecinde ele alınmakta, müracaatçının varoluşuna ilişkin otantik seçimiyle ya da kavrayışıyla yaşamın anlamını bulması mümkün olabilmektedir.

Sonlandırma Varoluşçu terapi ile ilgili literatür, müracaatçıların tedaviye getirdikleri ya da tedavi süresince keşfettikleri sorunlar ve ilgilere ilişkin öyküler bakımından oldukça zengindir. Randall (2008: 331) birçok çalışmada (Yalom, 1980; May ve Yalom, 1995; Lantz, 2001; Randall, 2001; van Deurzen-Smith, 1997, 2002; Imes vd., 2002; Cooper, 2003; Corey, 2008) müracaatçı değişim ve gelişimine ilişkin süreç yorumlarının ve anekdotların kayıtlarda yer aldığını belirtmektedir. Ancak çoğunluğunda herhangi bir aşamadan ya da tedavi aşamasından yeterince bahsedilmediği, benzer şekilde sonlandırmaya ilişkin örneğin; değişimin genelleştirilmesi ve devamının sağlanması ya da sonlandırmanın yapılandırılması ile ilgili çok az bilgi verildiği belirtilmektedir (Randall, 2008: 331).

Lantz (2001: 250) “yeniden yönlendirme (redirection)” diye adlandırdığ son aşamada, onaylama ve kutlama temalarına yer vermektedir. Sosyal hizmet uzmanı ve müracaatçı, müracaatçının gelişimini kutlamakta, sonra da yardım ilişkisi sonlandırılmaktadır. Bu anlamda sonlandırma, müracaatçının gelişimini sürdürme becerisi için hem müracaatçı hem de sosyal hizmet uzmanı tarafindan yapılan bir onaylama olmaktadır.

Değerlendirme Sosyal hizmet uygulama sürecindeki değerlendirme, aslında her aşamada gerçekleştirilmektedir. Uygulama süreci sonundaki değerlendirmede 
(evaluation), belirlenen hedeflere ulaşılıp ulaşılmadığ 1 , ne kadar ulaşıldığ ulaşılamadıysa bunun önündeki engeller, bireysel güçler vb. konularda derinlemesine değerlendirmeler yapılmakta, seçimlerin ve değişimlerin hayata geçirilerek sürdürülmesi üzerinde durulmaktadır.

Varoluşçu terapilerde değerlendirme, çıktıları zaman içinde aramaya devam etme şeklinde gerçekleşmektedir (Randall, 2008: 332). Olmak, öznellik ve olguculuk gibi içsel durumlara yaptıkları vurguyla varoluşçu analiz, kanıta dayalı uygulama ilkelerinin epistemolojik varsayımlarına her zaman uygun değildir. May ve Yalom (1995: 285), semptomatik rahatlama ya da davranış değişiminin makul kesinlikle ölçülebileceğini belirtmektedir. Cooper (2003: 148) ayrıca, niteliksel araştırma yöntemlerinin, varoluşçu terapiler ile kanıta dayalı uygulama arasında köprü olacak en iyi yol olduğunu savunmaktadır. Tüm bunların yanında Walsh ve McElwain (2001; akt. Randall, 2008: 332), varoluşçu terapilerin etkililiği ve çıktıları konusundaki nicel araştırma sayısının oldukça sınırlı olduğunu vurgulamaktadır.

Buraya kadar belirtilenler, varoluşçu analizin birey odaklı sosyal hizmet düzeyindeki açıklamalarını içermekteydi. Mezzo ve makro düzeyde, başka bir ifadeyle grup, toplum ve politika düzeyinde varoluşçu sosyal hizmet tartışmasının nasıl yapılabileceğine, birey boyutuna ilişkin yapılan değerlendirmeler ve varoluş felsefelerinin genel ilkeleri göz önünde bulundurularak bakılmasında yarar vardır.

\section{Grup Odaklı Varoluşçu Sosyal Hizmet}

Sosyal hizmet uygulamasının mezzo düzeyinde, en yalın şekilde açıklamak gerekirse, benzer sorunu yaşayan veya benzer ihtiyaçları paylaşan bireylerle ele alınan, konunun içeriğine ve belirlenen hedeflere göre grup çalışması gerçekleştirildiği belirtilebilir. Varoluşçu grup yaklaşımının, gerçek yaşamın küçük bir kesiti gibi olduğunu söylemek mümkündür. Corey (2008: 223), varoluş̧̧u gruplarda üyelerin çeşitli amaçlarla yolculuğa çıktığını, bu yolculuğun liderin yönlendirmesi ile değil, bireylerin kendi farkındalıklarını kazanmaları ile gerçekleştiğini ve üyelerin içten bir şekilde kendilerini açmaları sonucunda grupta yakın ilişskiler kurmayı başardıklarını belirtmektedir.

Varoluşçu grubun en temel amacı, kişisel farkındalığı geliştirmektir. "Ben kimim, nereye gidiyorum?" sorularına yanıt arayan grup üyeleri, bireysel sorumluluklarının da farkına vararak anksiyete ile baş etme ve anksiyete ile baş ederek yaşamın anlamını arama gibi diğer amaçlara da ulaşmaktadırlar (Gladding, 2008; akt.: Kağnıc1, 2013: 292).

Varoluşçu görüşün temel kavramları olan farkındalık, özgürlük, sorumluluk, varoluşsal anksiyete, ölüm, anlam arayışı, yalnızlık ve bağlılık, varoluşçu gruplarda ele alınan temel konulardandır (Corey, 2008: 225). Varoluşçu gruplarda grup liderinin temel görevi, üyelerin birbirleri ile anlamlı ilişkiler kurmalarına yardımcı olmak ve temel varoluş anksiyetelerini ele alabilecekleri uygun ortamlar yaratmaktır (Kağnıc1, 2013: 292). Corey (2008: 239), grup liderinin aynı zamanda üyelerin özgürlüklerini engelleyici etmenleri görmeleri, seçimlerini nasıl 
çeşitlendirebilecekleri ve seçimleri konusunda sorumluluk almada üyeleri cesaretlendirerek yaşamlarını incelemelerinde onlara bir çeşit meydan okuduklarını belirtmektedir.

Grup üyelerinin "şimdi” ve "burada" yaşadıklarına odaklanan grup lideri, "Kim olduğun konusunda farkındalığın ne kadar yüksek?", "Neler yaşıyorsun ve yaşadıklarına ne anlam yüklüyorsun?", "Kendin hakkında her şeyi öğrenmeye açık mısın?", "Farkındalığını genişletmek için istekli misin?", "Şimdi kapalı olan kapıların açılması yaşantını nasıl etkiler?" gibi sorular sorarak üyeleri kendileri hakkında düşünmeye yönlendirmektedir (Kağnıc1, 2013: 293; Koçak ve Gökler, 2008: 99).

Grup lideri üyelere, özgürlük ve sorumluluk bilinci kazanma, kaygı ile baş etme, ölüm ile yüzleşme, yaşamdaki anlam konusunda kavrayış geliştirme, otantik olma, yalnızlık gibi konularda çeşitli sorular yönlendirmektedir. Bu sorulardan bazıları şöyle sıralanabilir; "Özgürlüguünüzü elde etmek ve seçim yapmak için kendinizi ne kadar hazır hissediyorsunuz?", "Hayatınız için kritik kararlar vermede ne tür kaygılar yaşamaktasınız?", "Hangi durumlarda daha yoğun kaygı yaşıyorsunuz?”, “Ölüm gerçeğini nasıl kabul edersiniz?”, “Ölümden önce başarmak istedikleriniz nelerdir?", "Size yakın birini kaybettiyseniz bunun sizin için ne anlama geldiğini grupla paylaşabilir misiniz?", "Bu yaşantıdan kendiniz hakkında ne öğrendiniz?", "Beş yıl önceki sıradan bir güne geri dönün. Yaşantınızdaki şimdiki ve sonraki önemli farklılıklar nelerdir?”, "Gelecek beş yıl için planınız nedir?", "Tek başınıza kalmak için kendinize zaman yaratıyor musunuz?", "Tek başına kalmak sizin için genel olarak ne ifade etmektedir?", "Yaşam kaliteniz hakkında ne düşünüyorsunuz?", "Eğer öleceğinizi bilseniz, yaşamınız hakkında ne hissederdiniz?", "Yaşamınızda sizi en çok tatmin eden şeyler nelerdir?" gibi sorular sorarak grubun desteği ile üyelerin yeni içsel anlamlar bulmalarına yardımcı olmaktadır (Corey, 2008; Kağnıcı, 2013: 293; Koçak ve Gökler, 2008: 99- 101).

\section{Varoluşçu Sosyal Hizmetin Makro Boyutu}

Sosyal hizmet uygulamasının makro düzeyi genel ifadeyle, toplumla çalışmayı, politika ve hizmet üretmeyi, var olan politika ve hizmetleri müracaatçı yararına geliştirip değiştirmeyi içermektedir. Varoluşçu görüşün birey ve grup düzeyindeki uygulamalarını ele almak ve değerlendirmek, makro düzey analizde bulunmaya göre görece daha kolaydır. Ancak ortak ilke ve temalarından hareketle çerçevesi çizilebilecek olan varoluş felsefelerini makro boyutta incelemek ve tanımlayabilmek oldukça güç ve hatta kimi varoluşçu düşünürlere göre imkânsızdır. Bireyciliğe aşırı yer veren, kişinin varoluş sorununa büyük ilgi gösteren bir felsefi akım olan varoluş felsefelerine toplumsal bir boyut kazandırmak her şeyden önce varoluş felsefelerinin kendi ilke ve temaları açısından sakıncalı bulunmaktadır.

Bunun yanında, varoluş felsefeleri gözünden bir toplum algısının; insandantopluma, toplumdan- insana köprü vazifesi gören, insan odakl1, toptancı toplum 
anlayışına karşı, kişilerin öznelliklerini yansıtabildikleri bir toplum inşası açısından oldukça verimli bir egzersiz olduğunu da vurgulamak gerekmektedir.

Varoluş felsefeleri içinde özellikle Sartre'ın bireyden hareketle makro düzeyde açıklamalar getirdiğini görmek mümkündür. Sartre (2009: 41), “(...) insan sorumludur derken yalnız kendinden değil, bütün insanlardan sorumludur (...)”; “(...) insan olmak istediği kimseyi yaratırken herkesi yaratır, başka bir ifadeyle, "kendisini seçerken herkesi seçer" demektedir. Benzer şekilde, "(...) insanın evrenselliği vardir ve bu evrensellik doğarken kazanılmaz (...) Kişi kendini oluştururken toplumu da oluşturur. Varoluşçu felsefelere göre insana yüklenen bütün özellikler ancak başkalarlyla olan ilişkilere göre belirlenirler" diyen Sartre (2009: 63), alternatif ve bireyin öncelikli olduğu bir toplum algısını yansıtmaktadır.

Varoluş felsefeleri, kişinin kendini tanıyabileceği, özüne ulaşabileceği, öznelliği baskı altında olmayan bir toplum yapısı düşüncesindedirler. Bezirci (2009: 11)'ye göre, kişinin bireyselliğini ve öznelliğini baskı altına alan toptancı bir toplum düşüncesine karşıdırlar. Buradan hareketle Kierkegaard, bireyi ana gerçek saymakta ve toplumu hor görmektedir. Marcel, hayatın toplumsallaştırılmasına öfkelenmektedir. Wahl, bugünkü düzende "bireyin varoluşunun büyük bir kumarda öne sürülen para gibi tehlikeli" olduğuna inanmaktadır. Sartre'a göre bireyin bu tehlikeden kurtulması, sorumluluk üstlenmesine ve durumunu kavramasına bağlıdır. “(...) Madem dünyaya atılmıştır, kendi başına bırakılmıştır, o halde yaptıklarından sorumludur. Nitekim o, kendini nasll kurarsa öyle olacaktır. Tasartlarına, seçimlerine ve eylemlerine göre varlığına bir öz kazandıracaktır. Edimleriyle kendini gerçekleştirecektir ve gerçekleştirmelidir” demektedir.

Varoluş felsefeleri temel alınarak yapılanan varoluşçu analizin sosyal hizmet disiplin ve mesleğindeki uygulanışını, geçerliğini görmek ve daha iyi anlamak için varoluşçu sosyal hizmet uygulamalarına ve etkililiğine bakmak gerekmektedir. Genellikle birey ve grup düzeyinde gerçekleştirilmiş bu çalışmaların bazılarına metin içinde atıfta bulunulmuştur. Bu çalışmanın genel yapısı nedeniyle söz konusu uygulamalara yer verilmemiştir. Çalışmalara erişim konusunda okuyuculara kolaylık sağlamak için kaynakça bölümünde detaylı bilgi verilmektedir.

\section{DEĞERLENDİRME}

"Ne olursa olsun, insanın yapacă̆ bir gelecek vardır. El değmemiş bir yarın onu bekler."

Sartre

İnsana ve yaşama bakış yollarından olan varoluş felsefeleri, yerleşik felsefelere dayanmakta; ancak insanı, insan varoluşunu ve yaşamı ele alış yöntemindeki farklılıklardan dolayı onlardan ayrılmaktadır. Tek ve öz bir varoluş felsefesi tanımlaması yapma güçlüğü her ne kadar konunun anlaşılmasını güçleştirse de farklı varoluşçu düşünürler tarafında sunulan görüşlerin çeşitliliği, aslında insan 
varoluşuna ilişkin tek düze olmayan bir kavrayış sağlamaktadır. Konunun derinliklerine indikçe daha fazla bilgi ihtiyacı içinde olan insan hem varoluşuna hem de yaşamına ilişkin derin bir düşünce içine girebilmektedir. Eleştirel ve sorgulayan bir bakışla varoluşuna yaklaşan insan, kendine ilişkin farkındalık geliştirmenin yanında ölüm ve varoluşunun bir gün sonlanacağı gerçeği karşısında yaşamının anlamını arama yollarına gidebilmekte ya da tersi şekilde, sorumluluğu reddederek yaşamını sürdürmeyi seçebilmektedir. Her iki şekilde de kendi özünü seçen insanın ilk oluş biçiminde otantik olmayı seçtiğini, diğerinde ise var olamadığını söylemek mümkündür.

İnsan ve toplumun nasıl yaşaması gerektiğine ilişkin belirtilen ön beklentileri reddeden varoluş felsefeleri insanların, sürekli bir yeniden yapılanma sürecinde, ihtiyaç ve isteklerine göre özgürce yer alabileceği tam bir yeniden örgütlenmeyi "yeniden sosyalleşmeyi” amaçlamaktadır. Varoluşçu düşünceye göre, bu özgürlük insanların yabancılaşmayı yenmelerine imkân sağlamaktadır.

Varoluşçu görüşün, her ne kadar çağın bir gereği olarak yabancılaşan, yalnızlaşan ve var olamayan insanın ihtiyaç ve sorunlarını ortadan kaldırmak için ortaya çıkan bir akım olduğu ileri sürülse de, varoluş felsefelerine ve varoluş̧̧u terapiye ciddi eleştiriler yöneltilmektedir. May temel eleştirinin, öne sürülen fikirlerin kuramsal bir yapıda şekillendirilmemiş olmasından kaynaklandığını belirtmektedir. Varoluşçu görüşün bilimsel olarak sinanabilir belirgin hipotezler içermemesi ve bu nedenle de kurama dayalı olarak pek fazla ampirik araştırma yapılamaması, yöneltilen diğer eleştirilerdendir (akt.: Yazgan İnanç ve Yerlikaya, 2011: 343).

Karmaşıklaşan yaşam koşullarında ve karmaşıklaşan sorunlar yumağında pozitivist bilimsel yöntemin sınırlı kaldığı ve çözüm üretemediği bir gerçektir. Fenomonolojik ve ontolojik yapısıyla insan ve insan yaşamına mekanik yaklaşımın tersi şekilde yaklaşan varoluşçu düşünür ve terapistler, yaşanılan yabancılaşma duygusunun ve yaşamın anlamsızlığı sonucunda ortaya çıkan varoluşsal boşluğun, kişinin özgürce seçimler yapıp kendi özünü seçmesi ve varoluşsal anksiyete ile yüzleşerek kendi varoluşunu sağlaması ile ortadan kalkacağını belirtmektedir. $\mathrm{Bu}$ noktada, aslında benzer amaç ve hedefe sahip sosyal hizmet meslek ve disiplini ile varoluşçu görüş arasındaki ortaklık ortaya çıkmaktadır.

İnsan sorunlarını çözümlemek ve ihtiyaçlarını ortadan kaldırmak için bireyin katılımını odağa alan sosyal hizmet, yaşamı hakkında karar alacak tek ve en doğru kişinin, bireyin yani müracaatçının kendisi olduğunu savunmaktadır. İnsana bütüncül bir açıdan bakan sosyal hizmet anlayışı, bireyin özgürleşmesi, güçlerinin ortaya çıkarılması ve desteklenmesi yolu ile refahının sağlanması, varoluşçu düşünürlerin deyimiyle bireyin yaşamının anlamına ulaşması hedeflenmektedir. 


\section{KAYNAKÇA}

Bezirci, A. (2009). Varoluşçuluk'a önsöz. A. Bezirci (Çev.) Varoluşçuluk: İçinde (1-13). İstanbul: Say Yayınları. (Orijinal çalışma basım tarihi 1946).

Boylin, W. M. ve Briggie, C. R. (1987). The healthy therapist: The contribution of symbolic-experiential family therapy. Family Therapy, 14: 247256.

Brown, J. (1980). Child abuse: An existential process. Clinical Social Work Journal, 8 (2): 108-115.

Brown, J. ve Romanchuk, B. (1994). Existential social work practice with the aged: Theory and practice. Journal of Gerontological Social Work, 23 (1/2): 49 65 .

Charlesworth, M. J. (1976). The Existentialists and Jean-Paul Sartre. London: George Prior.

Chessick, R. (1996). Heidegger's "authenticity" in the psychotherapy of adolescents. American Journal of Psychotherapy, 50 (2): 208-216.

Corey, G. (2008). Theory and practice of group counselling. Belmont: Thompson Brooks/Cole.

Cooper, M. (2003). Existential therapies. London: Sage.

Dean, R. ve Fenby, B. (1989). Exploring epistemologies: Social work action as a reflection of philosophical assumptions. Journal of Social Work Education, 25 (1): $46-54$

Ford, G. (1996). An existential model for promoting life change. Journal of Substance Abuse Treatment, 13 (2):151-158. Yayınları

Foulquie, P. (1995). Varoluşçuluk. Y. Şahan (Çev.) İstanbul: İletişim

Frankl, V. E. (2009). Insanın anlam arayışı. S. Budak (Çev.) İstanbul: Okuyan Us Yayınları.

Fraternali, K. (1998). Sartre's existentialism and social work. Journal of New Global Development, 12 (1): 62-75.

Geçtan, E. (1974). Varoluşçu psikolojinin temel ilkeleri. Ankara Üniversitesi Eğitim Bilimleri Fakültesi Dergisi, 7 (1); 13-17.

Geçtan, E. (2007). Varoluş ve psikiyatri. İstanbul: Metis Yayınları.

Güleç, C. (2010). Pozitif ruh sağlı̆̆ı. Ankara: Arkadaş Yayınevi.

Gündoğdu, H. (2007). Varoluşçu felsefelerdeki bazı ortak özellikler. Dinbilimleri Akademik Araştırma Dergisi, VII (1): 95- 132. 
Hacker, D. (1994). An existential view of adolescents. The Journal of Early Adolescence, 14 (3); 300-327.

Haldane, D. ve McCluskey, U. (1982). Existentialism and family therapy: A neglected perspective. Journal of Family Therapy, 4 (2); 117-132.

Heinemann, F. H. (1959). Existentialism, religion and theology. Hibbert Journal: 58: 387.

Imes, S., Clance, P. R., Gailis, A. T. ve Atkeson, E. (2002). Mind's response to the body's betrayal: Gestalt/existential therapy for clients with chronic or lifethreatening illnesses. Journal of Clinical Psychology/In Session: Psychotherapy in Practice, 58: 1361-1373.

Kağnıcı, Y. D. (2013). Grupla psikolojik danışmada kuramsal yaklaşımlar: Varoluşçu kuram. A. Demir ve S. Koydemir (Der.) Grupla psikolojik danışma: İçinde (292- 294). Ankara: Pegem Akademi.

Kaye, J. (1986). My mind is alive and well and fouling up the system: Existential-phenomenological considerations in family therapy. Journal of Family Therapy, 8 (2):183-204.

Klugman, D. (1997). Existentialism and constructivism: A bi-polar model of subjectivity. Clinical Social Work Journal, 25 (3); 297-313.

Kominkiewicz, F. B. (2006). Heideggerian existentialism and social work practice with death and survivor bereavement. The social Science Journal, 43: 4754 .

Koçak, R. ve Gökler, R. (2008). Varoluşsal yaklaşımda psikolojik danışma ve gruba uyarlanışı. Sosyal Bilimler Araştırmaları Dergisi, 2: 91- 107.

Krill, D. (1986). Existential social work. F. J. Turner, (Der.) Social work treatment: Interlocking theoretical approaches: İçinde (179-205). NewYork: Free Press.

Krill, D. (1978). Existential social work. NewYork: Free Press.

Langiulli, N. (1997). European existentialism. New Jersey: Transactions Pub.

Lantz, J. (2001). Depression, existential family therapy, and Viktor Frankl's dimensional ontology. Journal of Contemporary Family Therapy, 23(1): 19-32.

Lantz, J. (1999). Existential marital psychotherapy and the experience of managed care. Journal of Couples Therapy, 8 (3-4); 109-114.

Lantz, J. (1994). Primary and secondary reflection in existential family therapy. Journal of Contemporary Family Therapy, 16 (4): 315-327.

Lantz, J. (1993). Existential family therapy: Using the concepts of Viktor Frankl. Northvale: NJ: Jason Aronson. 
Lantz, J. (1991). Franklian treatment with Vietnam veteran couples. Journal of Religion and Health, 30: 131-138.

Lantz, J. (1987). The use of Frankl's concepts in family therapy. Journal of Independent Social Work, 2 (2); 65-80.

Lantz J. ve Greenlee, R. (1990). Existential social work with Vietnam veterans. Journal of Independent Social Work, 5 (1): 39-52.

Lantz, J. ve Kondrat, M. (1997). Evaluation research problems in existential psychotherapy with couples and families. Journal of Family Psychotherapy, 8 (2); $55-72$.

Lantz, J. ve Pegram, M. (1989). Cross cultural curative factors and clinical social work. Journal of Independent Social Work, 4(1): 55-68. Yayınları.

May, R. (2012). Varoluşun keş̧i. A. Babacan (Çev.) İstanbul: Okuyan Us

May, R. ve Yalom, I. (1995). Existential psychotherapy. R. J. Corsini ve D. Wedding (Der.) Current pyschotherapies: İçinde (262-292). Itasca: Peacock.

Mounier, E. (2007). Varoluş felsefelerine giriş. (2. Baskı). (S. R. Kırkoğlu, Çev.). İstanbul: Say Yayınları. (Orijinal çalışma basım tarihi 1947).

Nilsson, I., Jansson, L. ve Norberg, A. (1999). Crisis phenomenon after stroke reflected in an existential perspective. International Journal of Aging and Human Development, 49 (4): 259-277.

Payne, M. (1997). Modern social work theory. NewYork: Palgrave Machmillan LTD.

Peebles, W. ve Suval, E. (1983). Traditional and educational philosophy: Relevance to baccalaureate curriculum development. Journal of Education for Social Work, 19 (2): 105-110.

Randall, E. J. (2001). Existential therapy of panic disorder: A single-system study. Clinical Social Work Journal, 29: 259-267.

Randall, E. J. (2008). Existential theory. N. Coady ve P. Lehmann (Der.) Theoretical perspectives for direct social work practice: A generalist-eclectic approach: İçinde (321-342). New York: Springer.

Sartre, J. P. (2009). Varoluşçuluk. A. Bezirci (Çev.) İstanbul: Say Yayınları. (Orijinal çalışma basım tarihi 1946).

Stretch, J. (1967). Existentialism: A proposed philosophical orientation for social work. Journal of Social Work, October: 97-102.

van Deurzen-Smith, E. (1997). Everyday mysteries: Existential dimensions of psychotherapy. New York: Brunner-Routledge. 
Varoluş Felsefeleri, Varolușçu... DEU Journal of GSSS, Vol: 19, Issue: 3

Wahl, J. (1964). Existentialisme'in tarihi. B. Onaran (Çev.) İstanbul: Elif Kitapevi.

Walsh, J. (1999). Incorporating existential themes into the supervision of social work practitioners. The Clinical Supervisor, 18 (1): 1-16.

Yalom, I. (2002). The gift of therapy. New York: Harper Collins.

Yalom, I. (2001). Varoluşçu psikoterapi. Z. İ. Babayiğit (Çev.) İstanbul: Kabalc1 Yayınları.

Yazgan İnanç, B. ve Yerlikaya, E. E. (2011). Kişilik kuramları. Ankara: Pegem Akademi. 